\title{
Temporal development of collar necroses and butt rot in association with ash dieback
}

\author{
Rasmus Enderle, \\ Felicitas Sander, \\ Berthold Metzler
}

\begin{abstract}
In recent years collar necroses and butt rot associated with the ash dieback disease occurred with alarming frequency in Fraxinus excelsior. We analysed tree ring structures to identify the year of necrosis initiation on a set of 507 necroses on 155 stem discs from nine severely diseased south-western German stands. The number of first-time infections of trees was highest from 2010 to 2012 and slightly decreased in 2013 and 2014, whereas the total number of newly emerging individual necroses remained high. Logistic modelling of disease progression suggests that collar rot infection has almost reached its maximum incidence and that a fraction of trees will remain healthy at the root collar. On average, Hymenoscyphus fraxineus was isolated more frequently from younger collar necroses, whereas older necroses were more often colonized by Armillaria spp. Advanced stages of rot that may pose a risk to forest workers, visitors and traffic were observed already in two years-old necroses infected by Armillaria spp.
\end{abstract}

Keywords: Ash Dieback, Collar Necrosis, Disease Progression, Armillaria, Butt Rot, Epidemiology

\section{Introduction}

Populations of Common ash (Fraxinus excelsior L.) and Narrow-leaved ash (F. angustifolia Vahl) in Europe are currently devastated by ash dieback, a disease of outstanding severity that strongly impairs the silvicultural utilization of these important broadleaf tree species. The agent of ash dieback is the ascomycete Hymenoscyphus fraxineus (T. Kowalski) Baral et al. (syn. H. pseudoalbidus Queloz et al.; anamorph: Chalara fraxinea T. Kowalski). According to current knowledge, the fungus has been introduced from Far East Asia to Europe about 25 years ago (Gross et al. 2013, Drenkhan et al. 2014). In south-western Germany, first traces of ash dieback have been dated back to the year 2006. Since 2009, the disease is omnipresent throughout this area (Metzler 2010).

Characteristic crown symptoms of ash dieback are necroses on leaves and dieback of shoots. Already in 2005, diseased root collars of ash trees have been re ported in combination with crown symp- toms of ash dieback, but were assigned to secondary pathogens (Lygis et al. 2005, Skovsgaard et al. 2010, Bakys et al. 2011). Only in 2012, it became clear that $H$. fraxineus can frequently be detected in diseased root collars (Husson et al. 2012).

The path of infection on root collars still remains unknown and it was not yet possible to directly demonstrate that $H$. fraxineus is the primary agent of these symptoms, but there is strong indirect evidence (Chandelier et al. 2016). Potential infection courts for $\mathrm{H}$. fraxineus at root collars may be lenticels, as hypothesized by Husson et al. (2012). After successful infection by $H$. fraxineus, the cambium is killed and characteristic, tongue-shaped discoloured bark necroses develop at the root collar. The sapwood proximal to the affected area dies and turns to a darker, brownish colour. Bark cracks become visible within one or two years. Xylem proximal to necroses is colonized by secondary agents that can cause butt and root rot. Very frequent pathogens in this regard are species of

Department of Forest Health, Forest Research Institute of Baden-Württemberg, Wonnhaldestrasse 4, 79100 Freiburg (Germany)

@ Rasmus Enderle (rasmus.enderle@forst.bwl.de)

Received: Feb 13, 2017 - Accepted: Apr 14, 2017

Citation: Enderle R, Sander F, Metzler B (2017). Temporal development of collar necroses and butt rot in association with ash dieback. iForest 10: 529-536. - doi: 10.3832/ifor2407-010 [online 2017-05-05]

Communicated by: Alberto Santin

honey fungus, mainly Armillaria gallica and A. cepistipes, but also A. mellea and A. borealis (Lygis et al. 2005, Bakys et al. 2011, Husson et al. 2012, Enderle et al. 2013, Hauptman et al. 2015, Chandelier et al. 2016, Marçais et al. 2016). In addition, some wood decay fungi of other genera and of minor importance have been reported (Heydeck \& Langer 2014, Langer et al. 2015).

Spatial patterns of collar necroses prevalence suggest an influence of site factors and there are indications for a predisposition of humid and wet sites (Husson et al. 2012, Enderle et al. 2013, Muñoz et al. 2015, Marçais et al. 2016). Moreover, there is a genetic component in susceptibility to collar necroses (Muñoz et al. 2015), as previously demonstrated for crown symptoms of ash dieback (McKinney et al. 2014 and references therein, Enderle et al. 2015b). Collar necroses occur more frequently on trees with high susceptibility to crown symptoms, but can also be observed on otherwise healthy trees (Husson et al. 2012, Enderle et al. 2013, Muñoz et al. 2015). Underlying resistance mechanisms of the different symptoms and possible relationships between them are still unknown.

Collar rots can occur in high prevalence, often cause substantial mortality and eventually are the most damaging factor associated with H. fraxineus (Husson et al. 2012, Metzler \& Herbstritt 2014, Chandelier et al. 2016, Marçais et al. 2016). Root and butt rot reduce the stability of the trees and can be a risk for foresty staff, forest visitors and traffic (Metzler et al. 2013, Kirisits \& Freinschlag 2014, Metzler \& Herbstritt 2014, Skovsgaard et al. 2017). Collar necroses also occur on narrow-leaved ash (F. angus- 
Tab. 1 - Location and characteristics of study sites. (1): According to forestry site maps (InFoGIS / ForstBW); (2): according to docu ments of local forest authorities or the mean number of year rings at stumps; (3): the number of stumps affected by collar necroses was counted either directly in the stands or on sampled stem discs.

\begin{tabular}{|c|c|c|c|c|c|c|c|c|}
\hline Site & Coordinates & $\begin{array}{l}\text { Altitude } \\
\text { (m a.s.l.) }\end{array}$ & Site conditions ${ }^{(1)}$ & $\begin{array}{l}\text { Sampling } \\
\text { date }\end{array}$ & $\begin{array}{c}\text { Mean } \\
\text { diameter }\end{array}$ & Age $^{(2)}$ & $\begin{array}{c}\text { No. } \\
\text { diseased }^{(3)}\end{array}$ & $\begin{array}{l}\text { Percentage } \\
\text { diseased }^{(3)}\end{array}$ \\
\hline $\mathrm{AC}$ & $\begin{array}{l}48^{\circ} 38^{\prime} 01^{\prime \prime} \mathrm{N} \\
08^{\circ} 01^{\prime} 15^{\prime \prime} \mathrm{E}\end{array}$ & 135 & Fresh fluvial loam & 02.2014 & 21.8 & 25 & 229 & 77.6 \\
\hline WE & $\begin{array}{l}48^{\circ} 13^{\prime} 33^{\prime \prime} \mathrm{N} \\
07^{\circ} 13^{\prime} 50^{\prime \prime} \mathrm{E}\end{array}$ & 167 & Moist floodplain & 10.2014 & 36.0 & 45 & 27 & 54.0 \\
\hline SE & $\begin{array}{l}47^{\circ} 49^{\prime} 33^{\prime \prime} \mathrm{N} \\
09^{\circ} 31^{\prime} 06^{\prime \prime} \mathrm{E}\end{array}$ & 560 & Marshy lower slope & 12.2014 & 31.6 & 45 & 43 & 89.6 \\
\hline FR & $\begin{array}{l}47^{\circ} 53^{\prime} 34^{\prime \prime} \mathrm{N} \\
09^{\circ} 31^{\prime} 55^{\prime \prime} \mathrm{E}\end{array}$ & 575 & Wet depression & 12.2014 & 58.0 & 65 & 11 & 68.8 \\
\hline $\mathrm{SH} 1$ & $\begin{array}{l}47^{\circ} 37^{\prime} 43^{\prime \prime} \mathrm{N} \\
07^{\circ} 47^{\prime} 24^{\prime \prime} \mathrm{E}\end{array}$ & 420 & Fresh depression & 05.2015 & 48.0 & 62 & 28 & 50.0 \\
\hline $\mathrm{SH} 2$ & $\begin{array}{l}47^{\circ} 38^{\prime} 06^{\prime \prime} \mathrm{N} \\
07^{\circ} 50^{\prime} 01^{\prime \prime} \mathrm{E}\end{array}$ & 450 & Humid depression & 05.2015 & 20.0 & 23 & 39 & 78.0 \\
\hline MS & $\begin{array}{l}48^{\circ} 22^{\prime} 32^{\prime \prime} \mathrm{N} \\
09^{\circ} 33^{\prime} 53^{\prime \prime} \mathrm{E}\end{array}$ & 762 & $\begin{array}{l}\text { Moderately dry residual material from } \\
\text { weathered limestone }\end{array}$ & 05.2015 & 19.6 & 32 & 26 & 52.0 \\
\hline HS & $\begin{array}{l}48^{\circ} 19^{\prime} 45^{\prime \prime} \mathrm{N} \\
09^{\circ} 19^{\prime} 48^{\prime \prime} \mathrm{E}\end{array}$ & 750 & $\begin{array}{l}\text { Moderately dry residual material from } \\
\text { weathered limestone }\end{array}$ & 05.2015 & 15.5 & 24 & 48 & 96.0 \\
\hline TR & $\begin{array}{l}48^{\circ} 18^{\prime} 28^{\prime \prime} \mathrm{N} \\
09^{\circ} 14^{\prime} 26^{\prime \prime} \mathrm{E}\end{array}$ & 720 & $\begin{array}{l}\text { Moderately humid residual material } \\
\text { from weathered limestone }\end{array}$ & 05.2015 & 46.2 & 49 & 5 & 25.0 \\
\hline
\end{tabular}

tifolia Vahl - Hauptman et al. 2015).

The aim of this study was to investigate the initiation and progression of this important disease in F. excelsior trees and stands, including the time course of the colonization of necroses by wood rotting fungi. The results are expected to provide a basis for decision-making and enhanced disease management in ash stands.

\section{Material and methods}

\section{Study sites and sampling}

In the context of consulting activities of the Forest Research Institute of BadenWürttemberg, nine pure ash stands with high prevalence of collar necroses have been reported by local forest authorities (Tab. 1). Harvesting operations were carried out shortly before investigation in these stands. Stumps of currently felled trees were investigated with differing intensity as described below. Discolorations of sapwood due to necroses and rots can be easily detected on stumps of recently felled trees (Fig. 1) and allow a more reliable survey of collar lesion prevalence than surveys on standing trees. In total, 155 stem discs with at least one necrosis were selected randomly (Tab. 2) and collected by sawing less than $10 \mathrm{~cm}$ above ground. The stem discs were about $4 \mathrm{~cm}$ in width.

\section{Dating of collar necroses and} reconstruction of prevalence history

The bottom sides of the stem discs were either grinded or planed. The year of necrosis formation was ascertained by analysing tree ring structures under a dissecting microscope. The year of the youngest unaffected tree ring was considered as the year of necrosis initiation. This was done for every individual necrosis separately except for stem discs from stand AC, where only the age of the oldest necrosis was identified per disc. These data and the data of prevalence of collar necroses at the time of sampling (Tab. 1) were used to retrospectively reconstruct the development of collar necrosis infection rate in the stands. A logistic curve was fitted to the mean percentage of infected trees by year of necrosis formation using the none-linear least squares method (R package "car" - Fox \&

Tab. 2 - Number of first-time infections per site and year on 155 investigated trees.

\begin{tabular}{lcccccccc}
\hline Site & Sum & $\mathbf{2 0 0 7}$ & $\mathbf{2 0 0 9}$ & $\mathbf{2 0 1 0}$ & $\mathbf{2 0 1 1}$ & $\mathbf{2 0 1 2}$ & $\mathbf{2 0 1 3}$ & $\mathbf{2 0 1 4}$ \\
\hline AC & 19 & 0 & 0 & 4 & 8 & 7 & 0 & - \\
FR & 11 & 0 & 0 & 0 & 7 & 3 & 1 & 0 \\
HS & 20 & 0 & 0 & 1 & 6 & 8 & 4 & 1 \\
MS & 17 & 0 & 0 & 1 & 6 & 4 & 4 & 2 \\
SH1 & 4 & 0 & 1 & 2 & 0 & 0 & 1 & 0 \\
SH2 & 6 & 0 & 0 & 2 & 2 & 1 & 1 & 0 \\
SE & 46 & 0 & 0 & 9 & 19 & 6 & 4 & 8 \\
TR & 5 & 1 & 0 & 0 & 1 & 1 & 0 & 2 \\
WE & 27 & 0 & 2 & 9 & 8 & 7 & 1 & 0 \\
Sum & 155 & 1 & 3 & 28 & 57 & 37 & 16 & 13 \\
Percentage & 100 & 0.6 & 1.9 & 18.1 & 36.8 & 23.9 & 10.3 & 8.4 \\
\hline
\end{tabular}

Weisberg 2011). This model has the following form (eqn. 1):

$$
y=\frac{\varphi_{1}}{1+e^{-\left(\varphi_{2}+\varphi_{3}+x\right)}}
$$

where $y$ is the percentage of infected trees, $\varphi_{1}$ is the upper asymptote, $\varphi_{2}$ and $\varphi_{3}$ are growing parameters and $x$ is the year. Logistic models are widely used to describe disease growth in the analyses of plant disease epidemics (Campbell \& Madden 1990, Van Maanen \& Xu 2003, Nutter 2007). The upper asymptote and the inflexion point of the sigmoid curve can be indicators for the final disease incidence (Holb et al. 2005, Shearer et al. 2007). For a highly susceptible host, the asymptote would be expected to be located at an infection rate of $100 \%$ and the inflexion point at an infection rate of $50 \%$. The inflexion point of the curve was determined with the $\mathrm{R}$ package "inflection" (Christopoulos 2016).

\section{Characterization of collar necroses and} rot

Sapwood proximal to necroses usually changes to darker, brownish colour after necrosis formation (Fig. 1a, Fig. 1b), but partly brightens up again with increasing degree of wood decay (Fig. 1c). The activity of certain wood-destroying fungi, Armillaria spp. in particular, is also indicated by the presence of demarcation lines in the wood (Fig. 1C).

All stem discs except discs from stand AC were visually categorized according to the proportion of the cross-section area that demonstrated indications of rot by using a ruler. They were divided into the following classes of rot intensity: (0) no indications of rot; (1) rot on less than $20 \%$ of the crosssection area; (2) rot on more than $20 \%$ of the cross-section area. Successful wound closure (Fig. 1e) was also recorded for 
Fig. 1 - Overview of differently developed collar necroses on investigated stem discs. (a): Stem disc with several young necroses; (b): advanced discoloration proximal to a bark necrosis; (c): partly brightening of discoloration due to wood decay and demarcation lines caused by Armillaria sp.; (d): severely affected cross section; (e): occasionally, successful wound closure was observed.
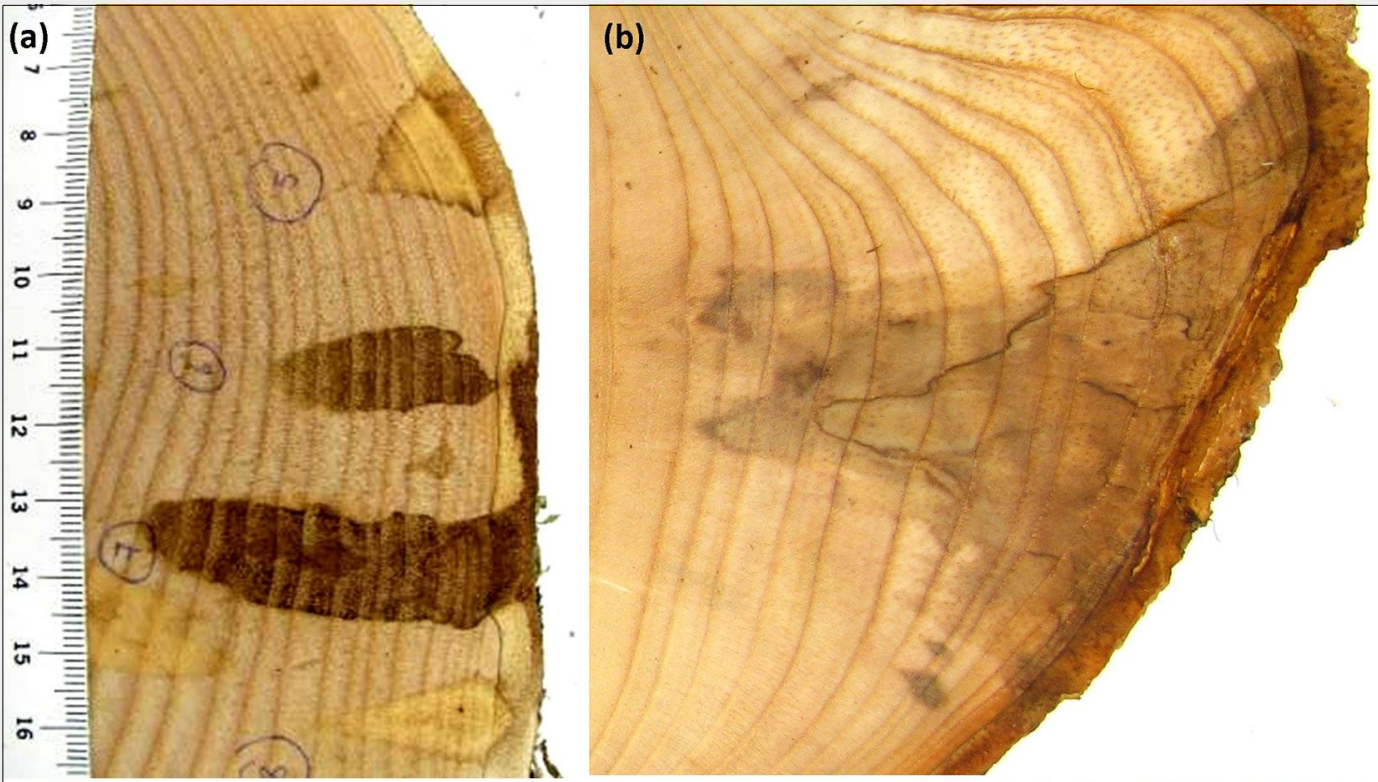

(c)
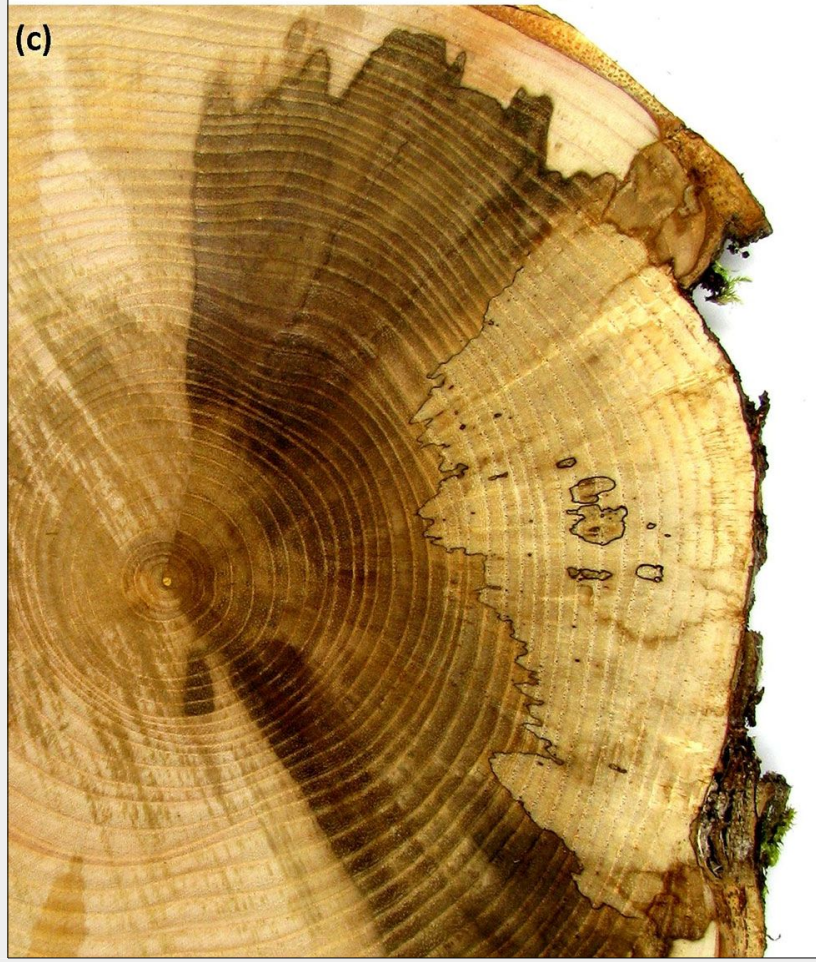
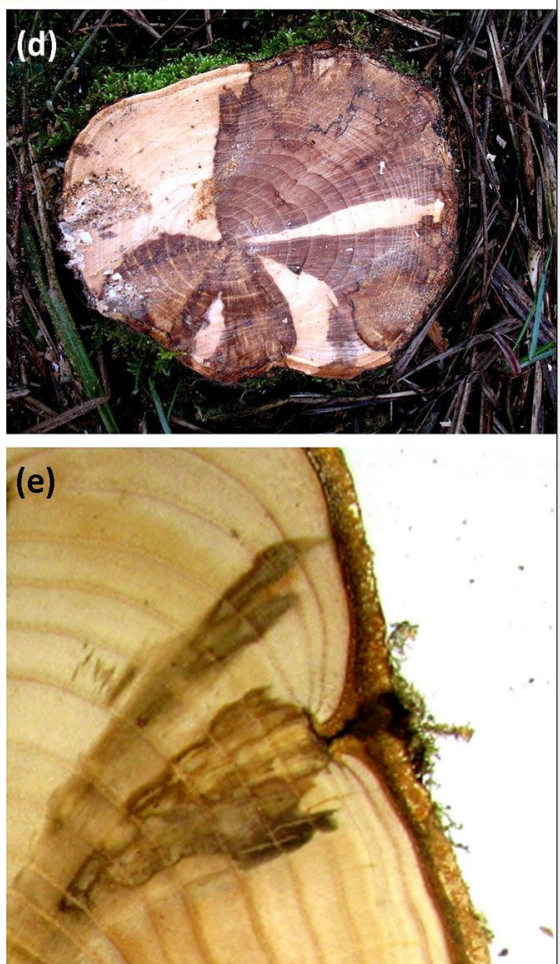

these stem discs. For all stem discs that originated from the sites $\mathrm{HS}, \mathrm{MS}, \mathrm{SH}_{1}, \mathrm{SH}_{2}$ and TR, the width of necrosis was measured along the cambium with a tape line.

\section{Occurrence of Armillaria spp.,}

\section{$H$. fraxineus and other microbes}

Necroses with characteristic rhizomorphs and white mycelial fans between bark and wood (Rhizomorpha subcorticalis) were classified as infected by Armillaria spp. (Garraway et al. 1991). All individual necroses were inspected in this way, except for stem discs from AC and WE. Here, infections by Armillaria spp. were documented only on the level of trees. A total of 73 necroses from the sites of HS ( 37 necroses) and MS (36 necroses) were randomly chosen for isolations of microbes. Xylem not deeper than $2 \mathrm{~cm}$ below the cambial necroses was radially split in the lateral advancing zone of the discoloration with a rack and pinion press (Metzler et al. 1993, Metzler 1997). Four specimens per necrosis (292 in total) of about $12 \mathrm{~mm}^{3}$ were taken immediately from the new, untouched surfaces with a cork borer under sterile airflow. Two specimens per necrosis were placed on synthetic nutrient-poor agar (SNA - Nirenberg 1981) and ash leaf malt agar (Kirisits et al. 2013), respectively, and incubated for three weeks at room temperature. The two culture media were used for a comparison of isolation success. Eight of the resulting Armillaria isolates were further analysed by molecular means according to Tsykun et al. (2013) in order to identify the Armillaria species.

\section{Results}

Development of symptom prevalence The first collar necrosis in the nine stands developed in 2007 in stand TR (Tab. 2). In stands WE and $\mathrm{SH} 1$, first necroses occurred in 2009, in the majority of stands in 2010. In 2011, collar necroses occurred in all stands. The majority of trees were infected in 2011 for the first time at the stem base. In subsequent three years, the number of firsttime infected trees decreased. The asymptote of the logistic model was located at $y$ $=65.3$, the inflection point at $y=34.2$ (Fig. 2 ), both indicating that final disease incidence will be less than $100 \%$.

Initially, the temporal development of individual necroses followed a similar pattern and only few necroses occurred before 


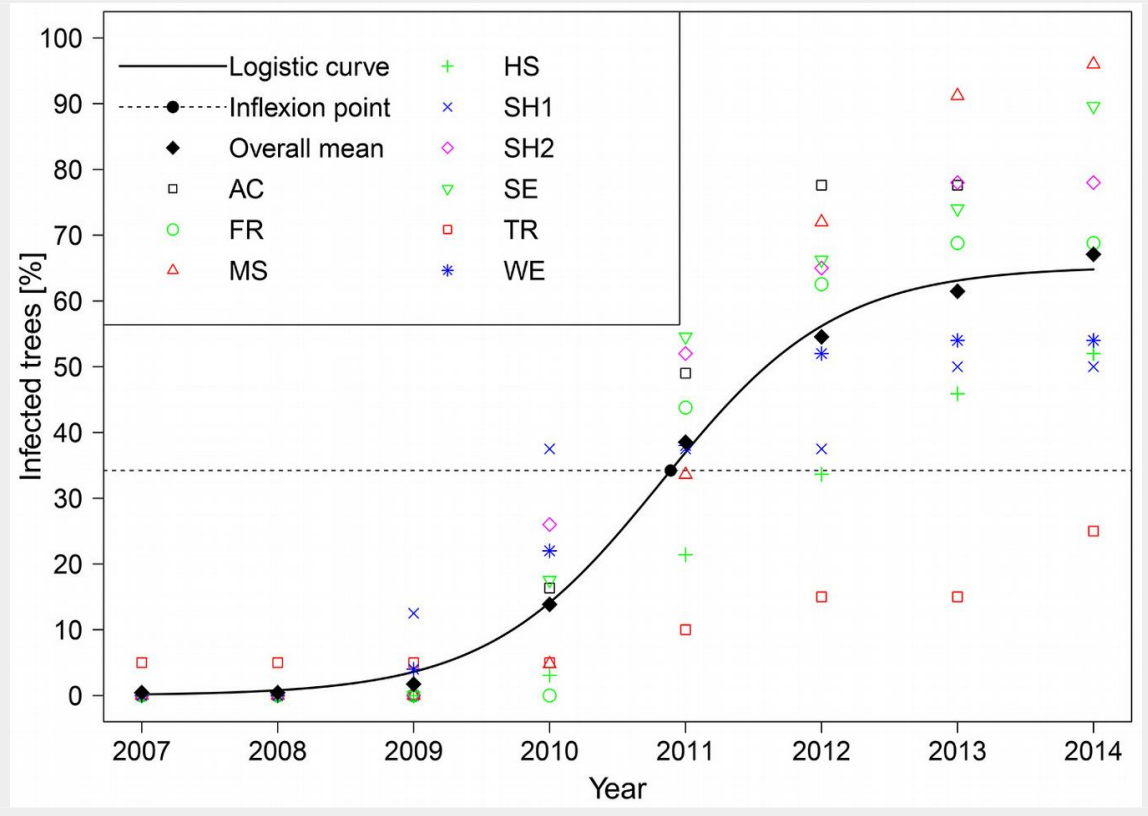

Fig. 2 - Temporal development of the proportion of infected trees in total and per stand, calculated from the year of first infection per tree and the proportion of infected trees at the time of sampling (see Tab. 1). Data for the stand AC ends in 2013.

Tab. 3 - Number of individual necroses and year of their formation.

\begin{tabular}{lcllllllllll}
\hline Site & Sum & 2007 & 2009 & 2010 & 2011 & 2012 & 2013 & 2014 & $\begin{array}{c}\text { Mean no. } \\
\text { per tree }\end{array}$ & $\begin{array}{c}\text { Maximum no. } \\
\text { per tree }\end{array}$ \\
\hline FR & 60 & 0 & 0 & 0 & 13 & 19 & 13 & 15 & 5.5 & 12 \\
HS & 61 & 0 & 0 & 1 & 10 & 18 & 14 & 18 & 3.1 & 7 \\
MS & 51 & 0 & 0 & 1 & 9 & 12 & 13 & 16 & 3.0 & 8 \\
SH1 & 19 & 0 & 1 & 3 & 0 & 1 & 12 & 2 & 4.8 & 8 \\
SH2 & 13 & 0 & 0 & 2 & 4 & 2 & 3 & 2 & 2.2 & 4 \\
SE & 232 & 0 & 0 & 16 & 49 & 33 & 31 & 103 & 5.0 & 16 \\
TR & 12 & 1 & 3 & 1 & 1 & 1 & 2 & 3 & 2.4 & 5 \\
WE & 59 & 0 & 2 & 14 & 12 & 20 & 10 & 1 & 2.2 & 5 \\
Sum & 507 & 1 & 6 & 38 & 98 & 106 & 98 & 160 & 3.3 & 12 \\
Percentage & 100 & 0.2 & 1.2 & 7.5 & 19.3 & 20.9 & 19.3 & 31.6 & - & - \\
\hline
\end{tabular}

2010 (Tab. 3). In the years 2011 to 2013, about a fifth of the investigated necroses emerged, respectively. Even more individual necroses occurred in 2014, particularly in the site SE.

\section{Isolates}

The results of the isolation experiment are presented in Tab. 4. In total, H. frax- ineus was isolated 94 times and detected in $58.9 \%$ of the investigated necroses and $67.6 \%$ of the stem discs. There was almost no difference in frequency of detection between the two stands (MS and HS) and the two culture media. Armillaria mycelium was isolated from 10 specimens. Bacteria (not further identified) emerged from 88 specimens. A total of 35 isolates were assigned to other fungal species: Fusarium sp. (three isolates), Phialophora sp., Cladosporium sp. and Acremonium sp. (two isolates, respectively), Trichoderma sp., Scytalidium lignicola, Exophiala sp. and Phoma sp. (one isolate, respectively) and 22 not identified fungal mycelia. No growth of microbes could be observed on 80 specimens (27.4\%).

\section{Characteristics of necroses of differing age}

Infections by Armillaria were detected on $58.4 \%$ of the 437 necroses that were tested either by isolation or by observation of characteristic mycelium or rhizomorphs. The temporal development of the colonisation by Armillaria spp. is presented in Fig. 3 . Only $10.4 \%$ of young necroses that experienced one complete growing season at maximum were infected by Armillaria. After two complete growing seasons $79.3 \%$ of necroses were colonized by Armillaria and the fungus was observed on $95.8 \%$ of necroses that experienced five complete growing seasons. A Mann-Whitney test for the year of necrosis formation between necroses infected and not infected by Armillaria was highly significant $(p<0.001)$. A contrary tendency was detected for the number of $H$. fraxineus isolates (Fig. 4), although the smaller sample number did not reveal significance in this case (MannWhitney test, $p=0.055)$. Successful isolation of $H$. fraxineus was particularly high for necroses that experienced only one complete growing season at maximum $(78.3 \%)$ and was smaller for older necroses. The pathogen could still be isolated from a necrosis that experienced five complete growing seasons.

The necroses width was significantly correlated with the time of necrosis formation (Spearman correlation, $\rho=-0.661 ; p<$ o.001). On average, older necroses colonized by Armillaria spp. were considerably wider than younger necroses. In contrast, such relationship was not evident when only necroses without Armillaria infection were considered (Fig. 5). Successful wound closure (Fig. 1e) of individual necroses was observed on 21 of 137 stem discs (15.4\%).

Almost one fifth (19.9\%) of the inspected stem discs were assigned to rot intensity class 2 (more than $20 \%$ of the cross-section

Tab. 4 - Number of isolated microbes per site (ME and HS), culture medium and in total and number of individual necroses with respective microbe detections.

\begin{tabular}{|c|c|c|c|c|c|}
\hline Counts & H. fraxineus & A. gallica & $\begin{array}{l}\text { Other } \\
\text { fungi }\end{array}$ & Bacteria & $\begin{array}{l}\text { Without } \\
\text { growth } \\
\text { of microbes }\end{array}$ \\
\hline Total no. of isolates & $94(32.2 \%)$ & $10(3.4 \%)$ & $35(12.0 \%)$ & $88(30.1 \%)$ & $80(27.4 \%)$ \\
\hline No. isolates in ME & $42(29.2 \%)$ & $5(3.5 \%)$ & 24 (16.7 \%) & $49(34.0 \%)$ & 32 (22.2 \%) \\
\hline No. isolates in HS & $52(35.1 \%)$ & $5(3.4 \%)$ & $11(7.4 \%)$ & $39(26.4 \%)$ & $48(32.4 \%)$ \\
\hline No. isolates on ash leaf agar & $45(30.8 \%)$ & 7 (4.8\%) & $12(8.2 \%)$ & $44(30.1 \%)$ & $40(27.4 \%)$ \\
\hline No. isolates on synthetic nutrient-poor agar & $49(33.6 \%)$ & $3(2.1 \%)$ & $23(15.8 \%)$ & $44(30.1 \%)$ & $40(27.4 \%)$ \\
\hline No. of necroses with isolates & $43(58.9 \%)$ & $7(9.6 \%)$ & $24(32.9 \%)$ & $50(68.5 \%)$ & $2(2.7 \%)$ \\
\hline No. of stem discs with isolates & $25(67.6 \%)$ & $6(16.2 \%)$ & $17(45.9 \%)$ & $31(83.8 \%)$ & $1(2.7 \%)$ \\
\hline
\end{tabular}




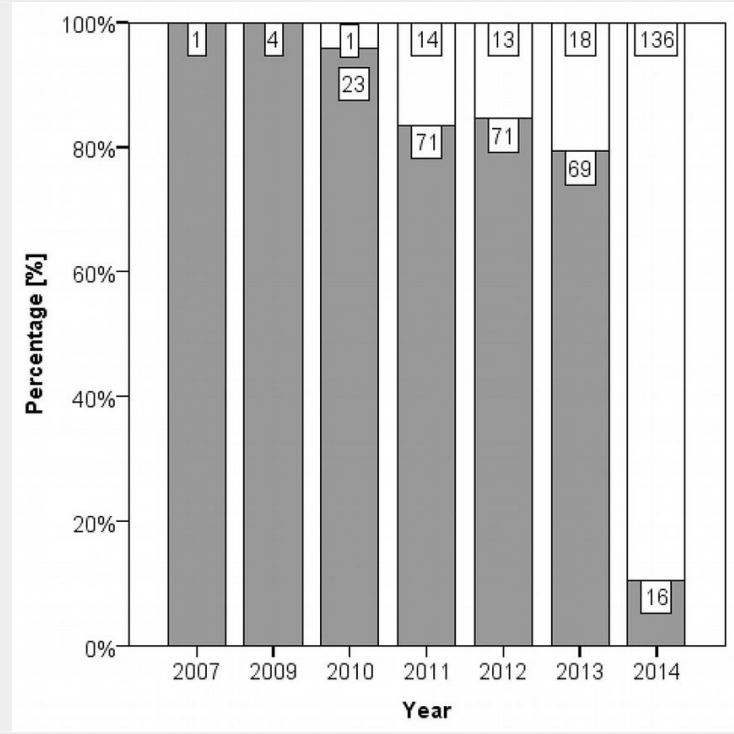

Fig. 3 - Proportion of individual necroses colonized (grey bars) and not colonized (white bars) by Armillaria spp. per year of necrosis formation. The number of necroses per category is displayed, respectively. There was no data for necroses from stands AC and WE.

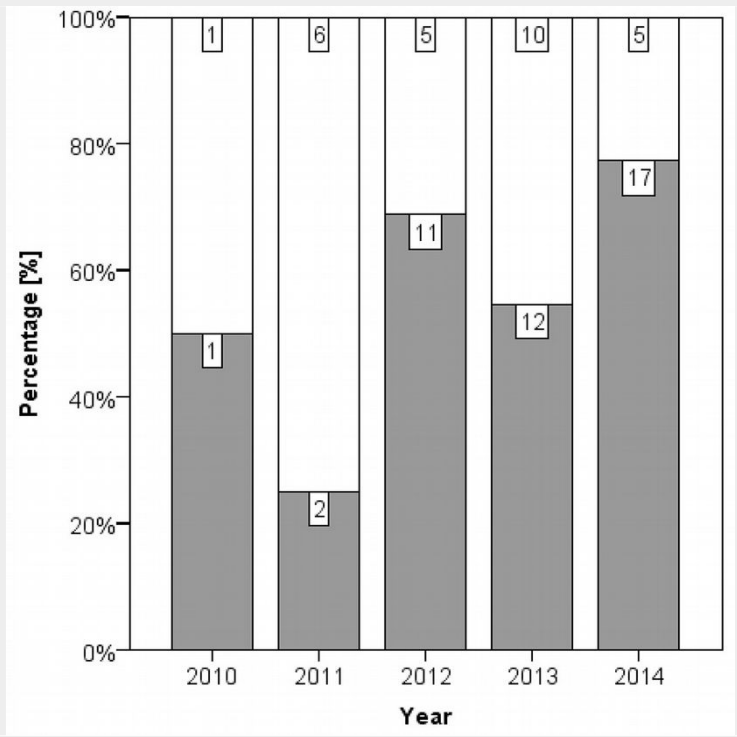

Fig. 4 - Proportion of necroses from stands HS and MS with detection by isolation of $H$. fraxineus (grey bars) and without detection (white bars) separated by year of necrosis formation. The number of necroses per category is displayed, respectively (70 in total). area). Less pronounced rot was observed on $64.7 \%$ of stem discs (rot intensity 1 ), whereas $15.4 \%$ of discs showed discoloration but no indications of rot (rot intensity o). Rot intensity was significantly correlated with the time of first necrosis formation (Spearman, $\rho=-0.420 ; p<0.001$ ). Indications for rot occurred on $23.1 \%$ of the discs that did not become diseased before 2014, but were local and all of rot intensity class $1.81 .2 \%$ of stem discs with oldest necroses from 2013 exhibited rot and one disc was even assigned to rot intensity class 2. The proportion of discs with rot intensity 2 increased with the time of infection and reached $41.7 \%$ for stem discs that were infected in 2010 for the first time. Significantly stronger rot intensity (MannWhitney test, $p<0.001$ ) was observed on stem discs that were colonized by Armillaria spp., whereas rot intensity class 2 occurred only once on a disc that appeared

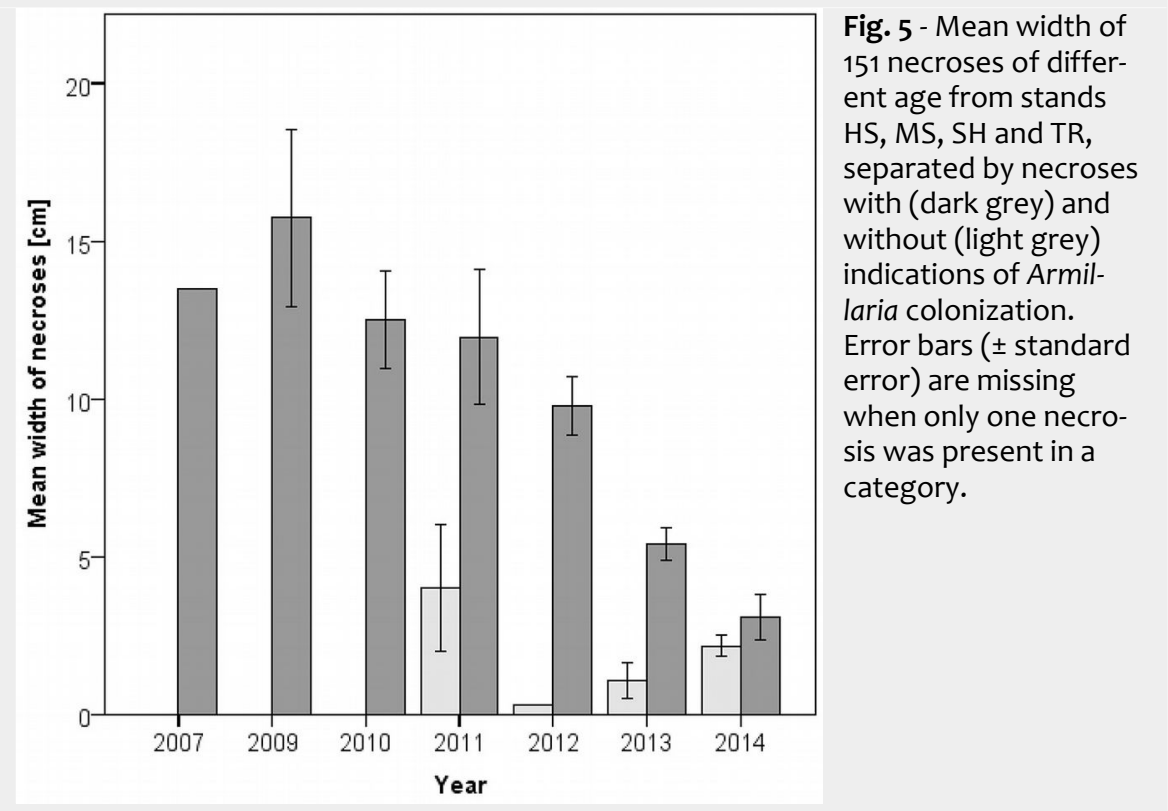

Fig. 6 - Percentage in classes of rot intensity and year of first infection per stem discs without (a) and with (b) indications of colonization by Armillaria spp. Rot intensity: (0) no indications of rot; (1) rot on less than $20 \%$ of the cross-section area; (2) rot on more than $20 \%$ of the cross-section area. The number of stem disc per category is displayed, respectively.

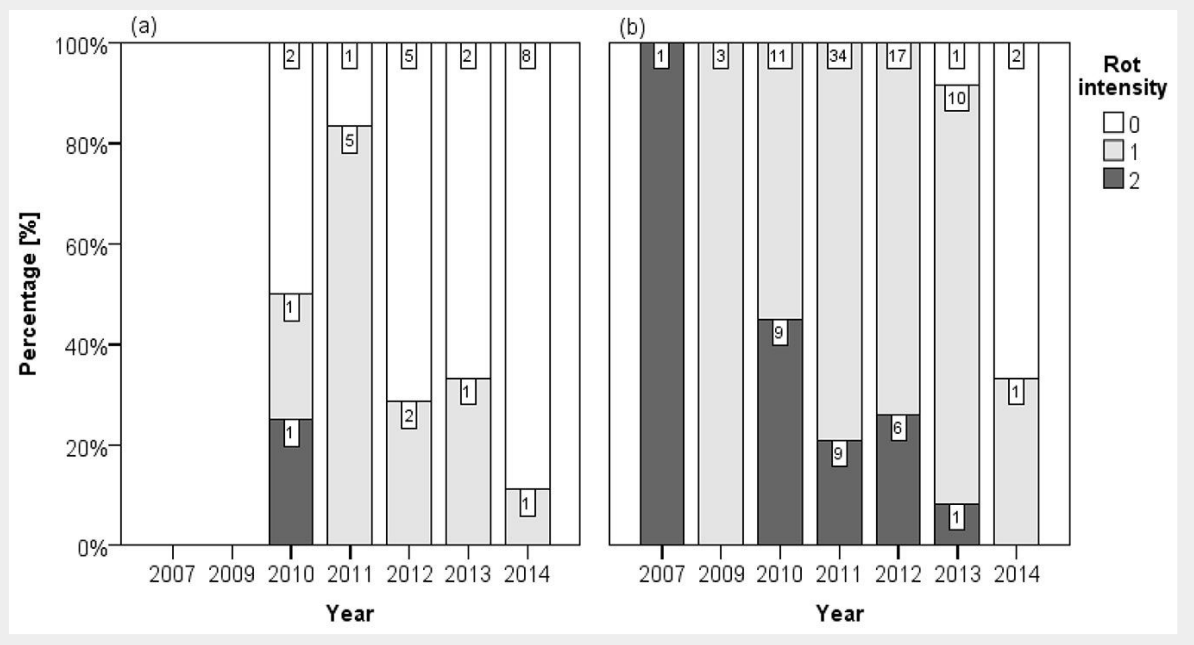


to be not infected by this fungus (Fig. 6).

\section{Discussion}

The retrospective approach of analysing tree ring structures revealed comprehensive information about the temporal development of collar necroses and butt rot including the colonization by the main pathogens $H$. fraxineus and Armillaria spp. New insights about the pathogenesis and recommendations for practitioners can be inferred from these results. In contrast to most other studies, we examined stumps of cut trees. This allowed investigating also young necroses that would not have been detectable on standing trees.

\section{Prevalence of collar necroses and site conditions}

The high prevalence of collar necroses in the investigated stands can be explained with their targeted selection. Moreover, it can be assumed that infection pressure by $H$. fraxineus and Armillaria spp. is higher in pure ash stands than in mixed stands. According to a representative survey for south-western Germany, ash trees with collar necroses accounted for only $17.5 \%$ of the total ash stock, whereby infection rate decreased with tree age (Enderle et al. 2015a). In this survey on standing trees, however, young necroses were probably not yet detectable.

The locally high frequency of collar necroses suggests site effects for prevalence. Indeed, data of several studies indicate that humid, wet, waterlogging and floodplain sites are predisposing for collar necroses (Husson et al. 2012, Enderle et al. 2013, Muñoz et al. 2015, Marçais et al. 2016). The majority of sites investigated in this study were humid, which supports the above cited findings. However, prevalence was also high in the sites ME and HS, which were categorised as moderately dry. Apparently, there are important factors other than site humidity that influence prevalence of collar necroses. Further studies that include, for example, the influence of tree age, are needed to clarify these very important interdependencies.

\section{Fungal isolates}

The method of sterile sampling used for isolation from fresh surfaces is advantageous over surface sterilisation, which can bias the isolation success. $H$. fraxineus was isolated with high frequency. Armillaria strains were isolated only scarcely, because specimens were sampled from the margins of discolorations, where the presence of Armillaria spp. is rather unlikely. Another study was able to detect $H$. fraxineus in 98 $\%$ and Armillaria spp. in $41 \%$ of necroses by molecular methods (Chandelier et al. 2016). These necroses did not provide any visual indications for the presence of Armillaria spp., and the authors assumed that frequency of this fungus can be underestimated in visual surveys. The two tested culture media (SNA and ash leaf agar) were similar in effectiveness for the isolation of Armillaria spp. and $H$. fraxineus. The latter grew faster on ash leaf agar, but phialides, which are important for the morphological identification of $C$. fraxinea, were easier to identify in SNA.

\section{Temporal development of collar necroses and rots}

According to the data presented, collar necroses started to become problematic in south-western Germany in 2010, which is four years after the first indications of the presence of $\mathrm{H}$. fraxineus (Metzler 2010). Also in France, the first collar necroses occurred later than crown symptoms and several years after the arrival of the pathogen (Husson et al. 2012, Marçais et al. 2016). The year 2011 was an inflexion point, as the number of first-time infected trees decreased in subsequent years (Fig. 2, Tab. 2). In theory, an inflexion point would be expected at an infection rate of $50 \%$ (Nutter 2007) and an asymptote for disease progression at an infection rate of $100 \%$ (Neher \& Campbell 1992), under the presumption that all individuals will become diseased. Inflexion points at lower infection rates suggest a lower final incidence of the disease (Holb et al. 2005). A similar assumption can be done for the asymptote (Shearer et al. 2007). The observed development suggests that a fraction of trees will remain in healthy conditions. This can be expected when assuming that currently uninfected individuals are less susceptible towards the symptom (Muñoz et al. 2015). Another possible explanation is that the remaining ash trees are growing in micro locations that are not suitable for collar infections. Of course, further monitoring is needed, as the presented time series comprises only few years and is too short for a reliable prediction of future infection development. However, general conditions in the years after 2011 apparently have been favourable to infection, as many collar necroses occurred at already infected trees (Tab. 3). Since most infections likely occur during the main time of sporulation, one may speculate that the high number of emerging individual necroses in 2014 is connected to the extraordinarily high precipitation during summer 2014 in the region: the mean precipitation in the Federal State of Baden-Württemberg was $191.6 \mathrm{~mm}$ in July and $115.6 \mathrm{~mm}$ in August, according to DWD (the German Meteorological Service).

The more frequent detections of Armillaria spp. on older necroses (Fig. 3) and the opposite pattern for $H$. fraxineus (Fig. 4) indicate that the necroses are primarily caused by the latter pathogen (Chandelier et al. 2016). Nevertheless, Armillaria spp. play an important aggravating role in this pathosystem. Obviously, necroses infected by Armillaria strongly enlarge over time (Fig. 5) and increasingly girdle the root collar, which is crucial for tree mortality. Collar girdling can also occur because of the accumulation of necroses (Marçais et al. 2016).
Although other wood decaying fungi can cause rot in ash collar necroses (Heydeck \& Langer 2014, Langer et al. 2015), our data demonstrate that extensive rots rarely occur in absence of Armillaria spp.

\section{Implications for forest management}

In forest management, collar necroses are relevant for two main reasons: (i) they dramatically increase tree mortality; and (ii) they reduce the stability of trees, which can be crucial for the safety of forestry workers, forest visitors and traffic. For timber marketing, collar necroses are of moderate importance, as they affect usually less than $1 \mathrm{~m}$ of the basal trunk. The wood quality of the remaining trunk is not compromised, if trees are harvested in time, i.e., before trees have lost more than $70 \%$ of the canopy or even have died (Metzler et al. 2013).

In the majority of cases, the anticipated mortality of the next years dictates the need for action in management of ash dieback affected stands. For the assessment of future mortality it is recommended to rate not only crown symptoms. At least on a random sample of trees, root collars should be inspected for the presence of necroses and butt rot, as described by Skovsgaard et al. (2017). Prevalence of these symptoms can change drastically within few years and operational decisions should not be made on a basis of older observations. Rot on more than $20 \%$ of the cross-section area was detected on a necrosis that was only two years old. We estimate that such extent of rot can already be a risk for forest workers and traffic.

Most trees affected by collar necroses are expected to die within a few year and/ or their growth performances to be strongly reduced. Such trees should be removed during thinnings similar to trees with strongly defoliated crowns (exceeding $70 \%$ - Metzler et al. 2013, Skovsgaard et al. 2017) in order to minimize risk of accidents. Exceptions may be trees with small, already closed necroses. Trees appearing resistant to the disease, also regarding collar necroses, should be conserved and their regeneration promoted.

The presence of Armillaria spp. is not to be expected in afforestation sites where thinnings were not yet conducted. The same likely holds for solitary trees, e.g., in parks or alongside roads. Under these circumstances, the situation of collar necroses can be considered much less severe. In the absence of Armillaria spp., rot was observed only rarely and only on several years old necroses.

\section{Conclusions}

Dating the time of collar necrosis formation by tree ring analyses revealed a typical sigmoid disease progression in a set of 155 trees from nine south-western German severely infested stands. Modelling of disease progression suggests that comparatively few trees will become first-time in- 
fected in the future and a fraction of trees will not become affected by collar necroses in the long term. However, future monitoring of disease incidence is necessary to confirm these results. The data supports the hypothesis that $H$. fraxineus is the major agent of collar necroses in ash, although Armillaria spp. play an important aggravating role. Ash trees colonized by Armillaria spp. begin to pose risks to forestry staff and forest visitors within two years after necrosis formation. Five years after necrosis formation, $41.7 \%$ of the affected root collars exhibited decay to a degree which we assume to be potentially hazardous.

\section{Acknowledgements}

We would like to thank the local forestry authorities of Emmendingen, Lörrach, Ortenaukreis, Ravensburg and Reutlingen for providing study sites and assistance in sampling. Further, we thank Gudrun Seiffert for the competent work on isolations and the identification of the Armillaria spp. and Niklas Ohlmann for the skilful assistance in $\mathrm{R}$ application. The study was funded by ForstBW.

\section{References}

Bakys R, Vasiliauskas A, Ihrmark K, Stenlid J, Menkis A, Vasaitis R (2011). Root rot, associated fungi and their impact on health condition of declining Fraxinus excelsior stands in Lithuania. Scandinavian Journal of Forest Research 26: 128-135. - doi: 10.1080/02827581.2010.536569

Campbell CL, Madden LV (1990). Introduction to plant disease epidemiology. Wiley, New York, USA, pp. 532. [online] URL: http://www.cabdi rect.org/cabdirect/abstract/19912305030

Chandelier A, Gerarts F, San Martin G, Herman $M$, Delahaye L (2016). Temporal evolution of collar lesions associated with ash dieback and the occurrence of Armillaria in Belgian forests. Forest Pathology 46 (4): 289-297. - doi: 10.1111/ efp. 12258

Christopoulos DT (2016). Inflection: finds the inflection point of a curve. $\mathrm{R}$ package version 1.2, website. [online] URL: http://CRAN.R-proj ect.org/package=inflection

Drenkhan R, Sander H, Hanso M (2014). Introduction of Mandshurian ash (Fraxinus mandshurica Rupr.) to Estonia: is it related to the current epidemic on European ash (F. excelsior L.)? European Journal of Forest Research 133 (5): 769-781. - doi: 10.1007/s10342-014-0811-9

Enderle R, Peters F, Nakou A, Metzler B (2013). Temporal development of ash dieback symptoms and spatial distribution of collar rots in a provenance trial of Fraxinus excelsior. European Journal of Forest Research 132: 865-876. - doi: 10.1007/s10342-013-0717-y

Enderle R, Kändler G, Metzler B (2015a). Eschentriebsterben [Ash dieback]. In: "Waldzustandsbericht 2015 für Baden-Württemberg" (Forstliche Versuchs- und Forschungsanstalt BadenWürttemberg ed). FVA, Freiburg, Germany, pp. 46-53. [in German]

Enderle R, Nakou A, Thomas K, Metzler B (2015b). Susceptibility of autochthonous German Fraxinus excelsior clones to Hymenoscy- phus pseudoalbidus is genetically determined. Annals of Forest Science 72: 183-193. - doi: 10.1007/s13595-014-0413-1

Fox J, Weisberg $S$ (2011). An $\{R\}$ companion to applied regression ( $2^{\text {nd }}$ edn). Sage, Thousand Oaks, CA, USA, pp. 472. [online] URL: http:// socserv.socsci.mcmaster.ca/jfox/Books/Compa nion

Garraway MO, Hüttermann A, Wargo PM (1991). Ontogeny and physiology. In: "Armillaria Root Disease" (Shaw CG III, Kile GA eds). USDA, Washington, DC, USA, pp. 21-46.

Gross A, Holdenrieder O, Pautasso M, Queloz V, Sieber TN (2013). Hymenoscyphus pseudoalbidus, the causal agent of European ash dieback. Molecular Plant Pathology 15: 5-21. - doi: 10.1111/ mpp.12073

Hauptman T, Ogris N, Groot M, Piskur B, Jurc D (2015). Individual resistance of Fraxinus angustifolia clones to ash dieback. Forest Pathology 46 (4): 269-280. - doi: 10.1111/efp.12253

Heydeck P, Langer G (2014). Xylobionte Pilze als bedeutungsvolle Folgepathogene des Eschentriebsterbens in Norddeutschland [Wood-inhabiting fungi as significant secondary pathogens of ash dieback]. Julius-Kühn-Archiv 227: 200-201. [in German]

Holb IJ, Heijne B, Withagen JCM, Gáll JM, Jeger MJ (2005). Analysis of summer epidemic progress of apple scab at different apple production systems in the Netherlands and Hungary. Phytopathology 95 (9): 1001-1020. - doi: 10.109 4/PHYTO-95-1001

Husson C, Caël O, Grandjean JP, Nageleisen LM, Marçais B (2012). Occurrence of Hymenoscyphus pseudoalbidus on infected ash logs. Plant Pathology 61 (5): 889-895. - doi: 10.1111/j.13653059.2011.02578.x

Kirisits T, Dämpfle L, Kräutler K (2013). Hymenoscyphus albidus is not associated with an anamorphic stage and displays slower growth than Hymenoscyphus pseudoalbidus on agar media. Forest Pathology 43 (5): 386-389. - doi: 10.1111/ efp. 12042

Kirisits T, Freinschlag C (2014). Eschentriebsterben: Wissensstand und Praxisempfehlungen [Ash dieback: state of knowledge and practical recommendations]. Kärntner Forstverein Information 73: 18-20. [in German]

Langer G, Harriehausen U, Bressem U (2015). Stammfußnekrosen bei Esche [Collar necroses on ash]. AFZ-Der Wald 70 (20): 29-31. [in German]

Lygis V, Vasiliauskas R, Larsson KH, Stenlid J (2005). Wood-inhabiting fungi in stems of Fraxinus excelsior in declining ash stands of northern Lithuania, with particular reference to Armillaria cepistipes. Scandinavian Journal of Forest Research 20: 337-346. - doi: 10.1080/02827 580510036238

Marçais B, Husson C, Godart L, Caël O (2016). Influence of site and stand factors on Hymenoscyphus fraxineus-induced basal lesions. Plant Pathology 65 (9): 1452-1461. - doi: 10.1111/ ppa.12542

McKinney LV, Nielsen LR, Collinge DB, Thomsen IM, Hansen JK, Kjaer ED (2014). The ash dieback crisis: genetic variation in resistance can prove a long-term solution. Plant Pathology 63 (3): 485-499. - doi: 10.1111/ppa.12196

Metzler B, Gross M, Mahler G (1993). Pilzent- wicklung in Fichtenholz unter Schutzgasatmosphäre [Fungal development in spruce wood in a protective gas atmosphere]. European Journal of Forest Pathology 23: 281-289. [in German] - doi: 10.1111/j.1439-0329.1993.tboog64.x

Metzler B (1997). Quantitative assessment of fungal colonization in Norway spruce after green pruning. European Journal of Forest Pathology 27: 1-11. - doi: 10.1111/j.1439-0329.1997.tb 00848.x

Metzler B (2010). Weitere Entwicklung des Eschentriebsterbens [Further development of ash dieback]. Waldschutz-INFO 3/2010, FVA Baden-Wuerttemberg, Germany, pp. 4. [in German] [online] URL: http://www.fva-bw.de/pub likationen/wsinfo/waldschutzinfo_3_2010.pdf Metzler B, Baumann M, Baier U, Heydeck P, Bressem U, Lenz H (2013). Bundesweite Zusammenstellung: Handlungsempfehlungen beim Eschentriebsterben [Nationwide compilation: recommended actions regarding ash dieback]. AFZ-Der Wald 68 (5): 17-20. [in German]

Metzler B, Herbstritt S (2014). Sicherheitsrisiko durch Stammfußnekrosen an Eschen, insbesondere auf Nassstandorten [Safety risks due to collar necroses on ash, especially on wet sites]. Waldschutz-INFO 1/2014, FVA Baden-Wuerttemberg, Germany, pp. 4. [in German] [online] URL: http://www.fva-bw.de/publikationen/wsin fo/wsinfo2014_01.pdf

Muñoz F, Marçais B, Dufour J, Dowkiw A (2015). Rising out of the ashes: additive genetic variation for susceptibility to Hymenoscyphus fraxineus in Fraxinus excelsior. Phytopathology 106: 1535-1543. - doi: 10.1094/PHYTO-11-15-0284-R Neher DA, Campbell CL (1992). Underestimation of disease progress rates with the logistic, monomolecular, and Gompertz models when maximum disease intensity is less than 100 percent. Phytopathology 82 (8): 811-814. [online] URL: http://www.apsnet.org/publications/phy topathology/backissues/Documents/1992Article s/phyto82no8_811.pdf

Nirenberg $\mathrm{HI}$ (1981). A simplified method for identifying Fusarium spp occuring on wheat. Canadian Journal of Botany 59 (9): 1599-1609. doi: 10.1139/b81-217

Nutter FF (2007). The role of plant disease epidemiology in developing successful integrated disease management programs. In: "General concepts in integrated pest and disease management" (Ciancio A, Mukerji KG eds). Springer, Netherlands, pp. 45-79. - doi: 10.1007/978-14020-6061-8_3

Shearer BL, Crane CE, Barrett S, Cochrane A (2007). Assessment of threatened flora susceptibility to Phytophthora cinnamomi by analysis of disease progress curves in shadehouse and natural environments. Australasian Plant Pathology 36: 609-620. - doi: 10.1071/AP07074

Skovsgaard JP, Thomsen IM, Skovgaard IM, Martinussen $T$ (2010). Associations among symptoms of dieback in even-aged stands of ash (Fraxinus excelsior L.). Forest Pathology 40: 718. - doi: 10.1111/j.1439-0329.2009.00599.x

Skovsgaard JP, Wilhelm GJ, Thomsen IM, Metzler B, Kirisits T, Havrdová L, Enderle R, Dobrowolska D, Cleary M, Clark J (2017). Silvicultural strategies for Fraxinus excelsior in response to dieback caused by Hymenoscyphus fraxineus. Forestry 2017: 1-18. - doi: 10.1093/for 
Enderle $R$ et al. - iForest 10: 529-536

estry/cpxo12

Tsykun T, Rigling D, Prospero S (2013). A new multilocus approach for a reliable DNA-based identification of Armillaria species. Mycologia

105 (4): 1059-1076. - doi: 10.3852/12-209

Van Maanen A, Xu XM (2003). Modelling plant disease epidemics. European Journal of Plant Pathology 109 (7): 669-682. - doi: 10.1023/A:102 6018005613 